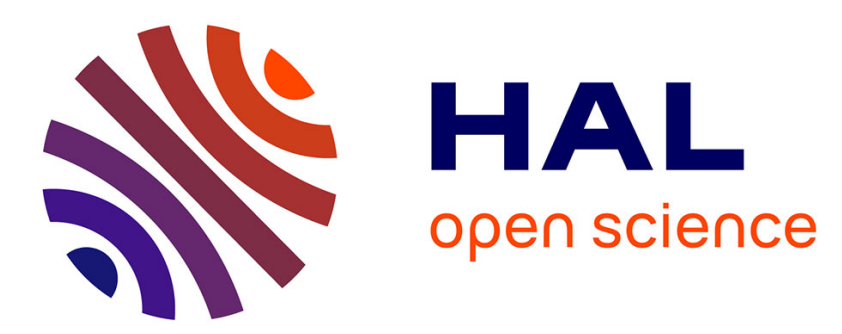

\title{
The formulation and implementation of policies to deal with groundwater overuse in Morocco: which supporting coalitions?
}

Nicolas Faysse, Mohamed El Amrani, Soufiane El Aydi, Ahmed Lahlou

\section{- To cite this version:}

Nicolas Faysse, Mohamed El Amrani, Soufiane El Aydi, Ahmed Lahlou. The formulation and implementation of policies to deal with groundwater overuse in Morocco: which supporting coalitions? 2012. cirad-00872497

\section{HAL Id: cirad-00872497 http://hal.cirad.fr/cirad-00872497}

Preprint submitted on 13 Oct 2013

HAL is a multi-disciplinary open access archive for the deposit and dissemination of scientific research documents, whether they are published or not. The documents may come from teaching and research institutions in France or abroad, or from public or private research centers.
L'archive ouverte pluridisciplinaire HAL, est destinée au dépôt et à la diffusion de documents scientifiques de niveau recherche, publiés ou non, émanant des établissements d'enseignement et de recherche français ou étrangers, des laboratoires publics ou privés. 


\title{
Formulation and implementation of policies to deal with groundwater overuse in Morocco: which supporting coalitions?
}

\author{
Nicolas Faysse ${ }^{1,2}$, Mohamed El Amrani ${ }^{2}$, Soufiane El Aydi², Ahmed Lahlou ${ }^{2}$ \\ ${ }^{1}$ Centre de Coopération Internationale en Recherche Agronomique pour le Développement (CIRAD), \\ G-EAU Research Unit, National Agricultural College of Meknès, Meknes, Morocco \\ ${ }^{2}$ National Agricultural College of Meknès, Meknès, Morocco
}

This is the pre-peer reviewed version of the article with the same title, which has been published in final form at http://onlinelibrary.wiley.com/doi/10.1002/ird.1652/full.

\begin{abstract}
The Moroccan administration is showing increasing interest in designing policies to tackle groundwater overuse. In particular, it aims to set up aquifer management contracts for the main overused aquifers, which should bring together broad coalitions of actors around coordinated supply and demand policies. This article analyses to what extent the actors involved in groundwater use and management come together for the definition and implementation of policies to deal with groundwater overuse in four regions. A broad coalition has been built around the design of an aquifer management contract only in the Souss. Catchment management agencies and the Ministry of the Interior collaborate to control the drilling of boreholes in the Saiss, Souss and Berrchid regions. Large-scale farmers in the Souss support the Ministry of Agriculture in developing more water resources. Small-scale farmers were involved in none of these coalitions. The depth of the aquifer, the importance of the groundwater economy in each region, and the motivation and capacities of actors help explain the diversity in the coalitions that were created. While such elements help define the specific needs to support coalition building in each case, in all cases, particular human resources and skills will be needed to catalyse such coalitions, as will innovative ways to include small-scale farmers.
\end{abstract}

KEY WORDS: coalition; demand management; groundwater; Morocco; policy 


\section{RÉSUMÉ}

Le gouvernement marocain montre un intérêt croissant pour concevoir des politiques permettant de faire face à la surexploitation des aquifères. Il cherche en particulier à concevoir des contrats de nappe pour les principaux aquifères surexploités. Ces contrats devraient rassembler de larges coalitions d'acteurs autour de politiques coordonnées portant sur l'offre et la demande en eau. L'article analyse dans quelle mesure les acteurs impliqués dans l'usage et la gestion des ressources en eau s'associent pour concevoir et mettre en œuvre des politiques pour faire face à la surexploitation des aquifères dans quatre régions. Une coalition a été construite autour de la conception d'un contrat de nappe seulement dans la région du Souss. Les agences de l'eau et le Ministère de l'Intérieur collaborent pour le contrôle des forages dans les régions du Saiss, du Souss et de Berrchid. Les agriculteurs de grandes exploitations dans le Souss appuient le Ministère de l'Agriculture pour la mobilisation de nouvelles ressources en eau. Les agriculteurs de petites exploitations ne sont présents dans aucune de ces coalitions. La profondeur de l'aquifère, l'importance de l'économie liée à l'usage agricole des aquifères, et la motivation et les capacités des acteurs contribuent à expliquer la diversité des coalitions qui ont été créées. Ces derniers éléments permettent de définir les besoins pour appuyer la conception de coalitions dans chaque cas. Cela dit, dans tous les cas, des ressources humaines et des compétences spécifiques seront nécessaires pour catalyser ces coalitions, de même qu'il faudra identifier des méthodes innovantes pour inclure les agriculteurs de petites exploitations.

MOTS CLES: coalition, gestion de la demande, eau souterraine, politique, Maroc

\section{INTRODUCTION}

In Morocco, achieving sustainable use of groundwater has become one of the most pressing issues in water resource management as many of the major aquifers of the country are already overexploited (Moroccan Secretariat in Charge of Water and Environment, 2007). After decades of relative absence of the State in dealing with groundwater overexploitation, the administration is now showing increasing willingness to address this issue. New policies are being implemented that consider both supply and demand management. The Moroccan Secretariat in Charge of Water and Environment also perceives the need to form large coalitions of actors around a set of coordinated policies in large-scale overused aquifers. For that reason, it has asked the Catchment Management Agencies (CMA), who are in charge of water resource 
management, to set up aquifer management contracts in ten large-scale overexploited aquifers. These contracts are intended to involve all major stakeholders.

The perceived need for coalition building corresponds to calls for considering the water sector as a complex system, where actions undertaken by a single actor are unlikely to have much effect on the sustainable use of water resources (Mollinga et al., 2007). Coalitions, which can be defined as groups of actors who coordinate their activities in order to achieve shared policy goals (Schlager, 1995), are increasingly seen as the key not only to ensuring the implementation of policies, but also in the policy choices made.

This is especially the case of groundwater use, as the goals and degrees of implementation of policies to control overexploitation are particularly sensitive to the type of coalitions formed. Indeed, there is a general lack of successful experience and blueprints to tackle groundwater overexploitation, especially in developing countries (Shah et al., 2007). As a result, there is no clearly-defined process to enable a shift from a situation of open access to one of sustainable use that would allow focusing on the creation of an appropriate coalition to ensure its successful implementation. Like surface water, the composition of the coalitions formed will influence the relative importance given to supply and demand management. Concerning the management of demand, coalitions may attempt to apply direct management of groundwater uses. For instance, in India, upper caste farmers in Rajasthan agreed to the state-led policy to control groundwater use and deliver tradable rights, because they hoped that such a reform would prevent lower caste farmers from having access to groundwater (Birkenholtz, 2009). Coalitions of actors may also favour more indirect approaches. Also in India, the government of Gujarat set up a dedicated electrical network for irrigation pumps, which made it possible to control the volume of water pumped and obtained the approval of the farmers as the energy supply became more reliable (Shah, 2009). However, the coalitions that are formed may not suffice to implement policies: the control of groundwater use that was planned to be implemented by groundwater user associations in Mexico was unsuccessful due to lack of support from both farmers and public organisations at federal level (Wester et al., 2011). Coalitions may also oppose policies to control groundwater overdraft. In several states in India, farmers lobbied against attempts to stop the supply of free electricity for groundwater pumping systems, even though this policy had repeatedly been identified as a major cause of groundwater overuse (Mukherji, 2006).

A wide range of policies and supporting coalitions thus exist that address groundwater overuse, both between and within countries (Mukherji and Shah, 2005; Shah, 2009). Several authors attempted to explain this diversity by comparative studies using different analytical frameworks (Faysse and Petit, 2012). Analyzing the attributes of users (as initially developed by 
Ostrom, 2000) and the behaviour of higher-level authorities made it possible to understand the differences observed in Spanish groundwater user associations (Lopez-Gunn and MartinezCortina, 2006). Mukherji (2006) showed that the difference in the strength of farmers' organisations and the local political setting helped explain why strict demand management measures were implemented in groundwater abundant West Bengal, while policies to curb the use of fragile aquifers in Gujarat were limited. In the same way, because of farmers' different incentives for implementing groundwater recharge, hard rock aquifers that are generally considered to be vulnerable may actually prove to be more appropriate for sustainable groundwater use than large-scale alluvial aquifers in India (Shah, 2012).

Policies to address groundwater overexploitation in Morocco share constraints commonly found in developing countries, such as the limited means of public organisations in charge of groundwater resources and the high number of informal water users. The proposed goal to build coalitions gathering all stakeholders through aquifer management contracts is more original, since this approach is usually used in developed countries (Petit, 2009). This article analyses to what extent the actors involved in groundwater use and regulation come together around the definition and implementation of policies to deal with groundwater overuse in four Moroccan regions and provides some explanations for the differences in the involvement of actors and in the constitution of coalitions. These explanations may help reflect on how to support the creation of coalitions able to define and implement policies for sustainable agricultural use of groundwater, and which also take into account the diversity of existing types of agriculture.

\section{METHOD}

The analysis was based on four study areas: the Souss-Chtouka, Saiss, Berrchid and coastal Chaouia aquifers (see Figure 1 and Table I for basic data). Interviews with public organisations were conducted in all four study areas, in particular with the CMAs and the local offices of the Ministry of Agriculture and Marine Fishery (hereafter referred to as MoA). Surveys of 40 farms were undertaken in the Souss and Saiss regions. Both interviews and surveys investigated: i) actors' assessment of the current state of groundwater resources and, if they were aware of a drop in the groundwater table, the reasons for this; ii) actors' understanding of and support for existing public policies to deal with groundwater overdraft, and possible involvement in their implementation; iii) actors' own proposals on how to achieve sustainable use of groundwater. These surveys were complemented by similar work with 155 farmers in Berrchid (Errahj et al., 2010) and 39 farmers in the coastal Chaouia (Berrahmani et al., submitted). Although several of the study areas also face problems of groundwater pollution, our analysis was limited to 
quantitative aspects. In addition, groundwater is also used for drinking water and industry in our study areas, but only agricultural use was analysed here, since agriculture is by far the largest groundwater user (e.g., $95 \%$ in Souss).

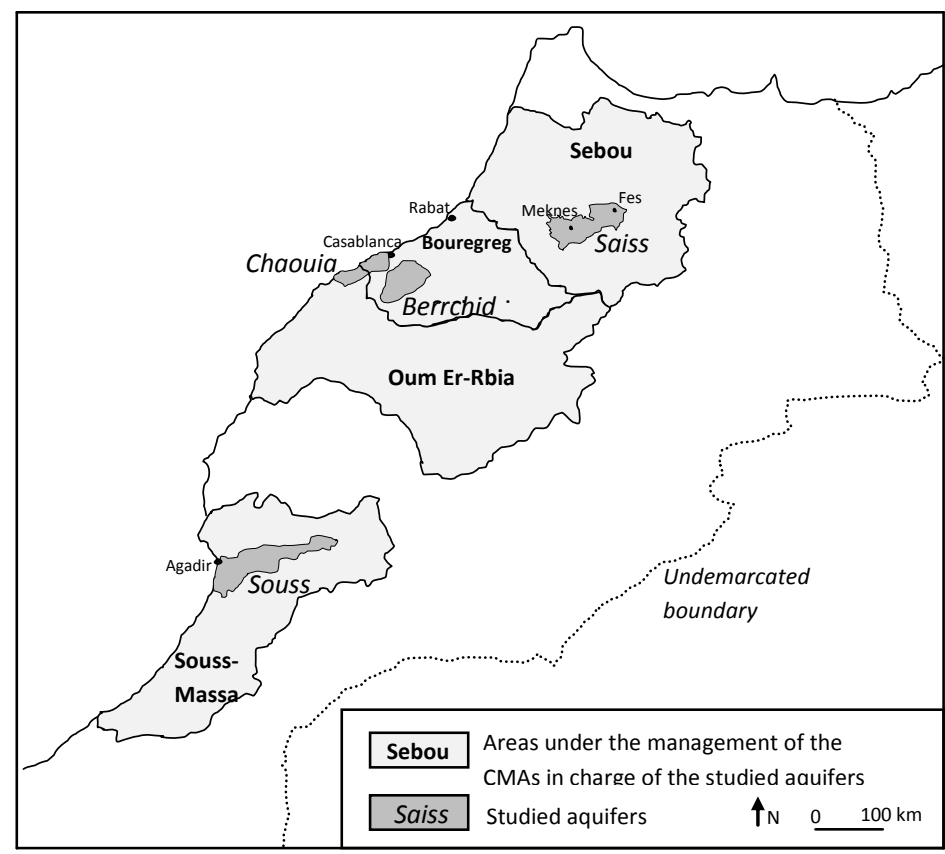

Figure 1. The aquifers studied in Morocco.

Table I. Basic data concerning the study areas.

\begin{tabular}{lcccc}
\hline & $\begin{array}{c}\text { Souss- } \\
\text { Chtouka }\end{array}$ & Saiss & Berrchid & $\begin{array}{c}\text { Coastal } \\
\text { Chaouia }\end{array}$ \\
\hline Total area $\left(\mathrm{km}^{2}\right)$ & 5,090 & 2,200 & 1,500 & 1,200 \\
Average irrigated area using groundwater (ha) & 122,100 & 38,000 & 18,000 & $*$ \\
Number of wells and boreholes & 20,000 & 8,000 & 1,700 & $*$ \\
Maximum depth of the aquifer (m) & 500 & 1,500 & 150 & 120 \\
Average decrease in the groundwater table in the & 2.5 & 3 & 0.5 & 0.5 \\
area of maximum decrease (m/yr) & & & & 10 \\
Average deficit (million $\mathrm{m}^{3}$ ) & 286 & 100 & 19 & 10 \\
Average groundwater withdrawal /average & $180 \%$ & $141 \%$ & $140 \%$ & $130 \%$ \\
recharge $(\%)$ & & & & \\
\hline
\end{tabular}

Source: interviews and CMA technical documents. * no recent data. 


\section{RESULTS}

Next we describe the policies that were planned and implemented to deal with groundwater overdraft in the four study areas, and then we describe the position of the main actors with regard to these policies, and the coalitions formed around these policies.

Policies specific to each area

The coastal Chaouia aquifer. In this area, groundwater overuse since the 1970s led to seawater intrusion in littoral land and decreasing groundwater levels further inland. Farmers had to adapt by changing cropping systems, by bringing fresh water to their farms, deepening boreholes or relocating to other regions. Groundwater stress was the main cause of the change in the region from intensive export-oriented agriculture to agricultural crisis. The Oum Er-Rbia CMA is responsible for the management of the western part of the aquifer and the BouregregChaouia CMA for the east. In practice, the CMAs only monitor piezometric levels and salinity rates. One reason is that, for both agencies, this aquifer is not of major importance compared to other larger aquifers and surface water issues. Thus the drilling and use of boreholes remains uncontrolled. Although around $90 \%$ of irrigation consists of drip irrigation (generally installed informally, without public subsidies), the groundwater balance still shows a deficit. In the 1990s, the local MoA office planned to set up a 2,500 ha irrigation scheme using water from the neighbouring Oum Er-Rbia River. In 2011, the project had not yet been implemented due to: i) lack of funding; ii) the absence of strong local farmers' organisations; iii) doubts over the availability of sufficient surface water and subsequent lack of support of the Oum Er-Rbia CMA.

The Berrchid aquifer. The shallow Berrchid aquifer is the main groundwater resource in the area under the responsibility of the Bouregreg-Chaouia CMA. According to this CMA, the overall water volume stocked in the aquifer decreased from 1,500 million $\mathrm{m}^{3}$ in 1980 to 800 million $\mathrm{m}^{3}$ in 2009. Water is fully depleted at the outskirts of the aquifer so farmers located in these areas have attempted to move to the centre of the aquifer where water is still available. According to the survey, 52\% of cropped area was farmed by tenants. Until 2010, most actions undertaken by the Bouregreg-Chaouia CMA focused on the supply side, with the construction of small weirs in river beds to increase groundwater recharge and of an irrigation scheme using treated waste water from the town of Berrchid. In 2011, the CMA held meetings to involve local public organisations, such as the local offices of the Ministry of the Interior and judiciary institutions, in the control of borehole drilling. This active stance resulted in the first seizure of a 
drilling machine in March 2011. The CMA planned to draw up an aquifer management contract, but had not yet started at the time of writing.

The Saiss aquifer. This aquifer comprises a superficial layer and a deep layer, although there are many hydraulic connections between the two layers. The decrease in the groundwater table in some parts of the deep layer was the fastest in the whole country, with an average rate of decrease of $3 \mathrm{~m} / \mathrm{yr}$. The Sebou CMA decided to stop delivering authorisations for new boreholes, except for farms of less than 5 ha, for which authorisations are still delivered. The CMA started to control the drilling of boreholes and seized some drilling machines that were operating illegally. Despite this action, the MoA gave the concession of 7,250 ha formerly managed by two parastatals to private investors. It approved the investment plans of these investors including drilling boreholes for irrigation, for which the CMA eventually delivered authorisation. One reason behind the stance of the MoA is the planned transfer of water from the Mdez dam (under construction in 2011) that should supply 120 million $\mathrm{m}^{3}$, which is more than the groundwater deficit calculated by the Sebou CMA. While water levels have been declining, only a small percentage of small-scale farmers were limited in their production as they lacked investment capacities to pursue falling groundwater levels. In 2011, the CMA hired a consultancy firm to prepare the aquifer management contract and have it signed by stakeholders.

The Souss and Chtouka aquifers. Here the neighbouring Souss and Chtouka aquifers are considered jointly, as is the case in most public policies, and the study area is hereafter referred to as the Souss region. These aquifers were the first in Morocco where the fall in the groundwater table became a subject of public concern (Popp, 1983). In 2004, the Souss-Massa Regional Council undertook a study to define a regional development strategy. This study ranked agriculture as a key component of the regional economy, with groundwater overdraft as its main Achilles heel. Indeed, in the El Guerdane area, groundwater overexploitation led to abandonment of the cultivation of 11,900 ha until a pipe was laid to bring water from an upstream dam. This project involved public subsidies and was the result of the active lobbying of large-scale farmers in the area concerned (Houdret, 2008). In 2005, the local CMA launched an initiative to control the drilling of boreholes and, in 2006, had stopped the drilling of 70 boreholes. In the same year, under the leadership of the Regional Council, a framework convention was negotiated and signed by the CMA, the Regional Council, the local offices of the MoA, the local Chamber of Agriculture, the regional federation of water user associations and three farmers' organisations involved in marketing citrus fruits and vegetables.

This convention outlined several actions to address the groundwater crisis. It had four components: 1) a decrease in water consumption and an increase in water productivity, mainly 
achieved by shifting from surface and sprinkler irrigation to drip irrigation and establishing a 'water police' force to control the drilling of boreholes; 2) more efficient irrigation practices and reuse of treated waste water; 3) use of deep groundwater resources; and 4) building of several small and medium-size dams. The funding required for these actions was estimated at around 3.5 million Euros per year and was to be provided by farmers who owned more than 15 ha. This category of farmers represents $20 \%$ of farms and $80 \%$ of pumped groundwater. After the signing of the convention, the coordination of its implementation was handed over to the SoussMassa CMA.

The Souss-Massa CMA defined three scenarios and in particular a positive one of 'governance' where groundwater overdraft would be almost completely stopped by 2020 . However, this prospective exercise did not lead to a shared vision among stakeholders regarding the desirable forms of agriculture and territorial development in the future. As a result, the framework convention focused on the process of reducing overexploitation, without clearly explaining the expected end results of such actions.

Coordination between the Souss-Massa CMA and the local offices of the MoA and of the Ministry of the Interior permitted the seizure of borehole drilling machines that operated illegally. Those in charge of control often intervened after having been informed either by neighbouring farmers or local authorities that an illegal borehole was being drilled. From 2006 to 2009,120 drilling machines were seized. In 2010, no drilling machine was seized, which was considered by the CMA as a sign that illegal borehole drilling had been drastically reduced. However, borehole drilling continued in 2011 due to understaffing of the water police and, according to many farmers interviewed, because some farmers managed to obtain the informal consent of the staff of either the CMA or the Ministry of the Interior. Moreover, farmers are allowed to replace a dried up borehole by a deeper one. Other actions undertaken in the frame of the convention were changing all existing surface irrigation systems to drip irrigation, and the planned creation of a 10,000 ha irrigation scheme using desalinized water in the Chtouka area, which, according to plans discussed in 2011, would profit from public subsidies.

\section{Policies common to the cases}

The MoA provides farmers with subsidies to change from surface to drip irrigation. These subsidies cover between 90 and $100 \%$ of the total cost (with a funding limit for each component of the irrigation system). There is a wide consensus among public actors that this policy is an appropriate way to limit groundwater use and 'save' water. However, many studies have shown that farmers who use groundwater and who change from surface to drip irrigation often do not 
reduce their groundwater withdrawal (Pfeiffer and Lin, 2011), and that the change has limited impacts on the water balance at catchment or aquifer basin level (Ward and Pulido-Velazquez, 2008).

The CMAs of the Berrchid, Saiss and Souss regions use a similar method to attempt to control groundwater use. First, a survey is undertaken to count existing wells and boreholes. The farmers are then asked to come to the CMA to register their existing wells and boreholes. In 2011 this procedure was underway in the Souss, Saiss and Berrchid. The situation was scheduled to be 'frozen' by February 2012, and, from then on, the CMAS planned that all unregistered boreholes subsequently discovered would be closed down. Farmers who registered their boreholes may then be asked to pay a specific tax for water consumption. This method faces two main difficulties. First, only a few farmers have come forward. In the Souss, only farmers who wanted to legally drill a borehole (for instance because they owned one that had dried out) or to obtain subsidies for shifting to drip irrigation (for which formal registration of the borehole is required) accepted to follow this formal procedure. In 2010, legalised boreholes amounted to an irrigated area of 5,000 ha in the Souss. The second difficulty is obliging farmers to pay the planned groundwater use tax. In 2010, a nationwide decree was enacted that enables the CMAs to take legal action against farmers who do not pay.

\section{Actors' positions}

Efforts by CMAs and by the Souss-Massa Regional Council to enrol actors. In all three study areas, the CMAs have a limited presence in the field and a limited capacity to monitor groundwater use. For that reason, they need support from other public organisations to be able to control groundwater use. The Souss-Massa Regional Council succeeded in building a coalition of public organisations both to coordinate groundwater management policies and to launch the water police force. In the same way, the CMAs in the Saiss and Berrchid areas were able to involve the local offices of the Ministry of the Interior, which became the CMA 'organ' for the implementation of the activities of the water police.

In the Saiss, the Sebou CMA was unable to obtain the support of other public organisations. This was particularly the case of the MoA, which supported further agricultural development. The MoA did not consider the situation to be critical, especially because of the expected transfer of water from the Mdez dam. The Sebou CMA took up the challenge and put forward a discourse of 'groundwater crisis'. While in the north-eastern part of the aquifer, the groundwater table is still at the same level as it was years ago, in its policy documents, the Sebou CMA systematically includes a graph of changes in the groundwater table in the area 
with the fastest decrease in the whole aquifer.

Using Gramsci's perspective (1971), the CMAs can be considered as simultaneously attempting to coerce the farmers and to obtain their consent for their policies. The CMAs' efforts to stop illegal drilling increased their power in their relation with the farmers. Indeed, after the first seizing of drilling machines in the Souss, farmers' organisations no longer considered that it was safer for them to remain outside the process of defining management policies. The CMAs also considered the aquifer management contracts as a tool to obtain the farmers' approval for the regulation of groundwater use.

Limited MoA and farmers' involvement. Apart from in the Souss, local MoA offices were not involved in the control of borehole drilling. The Souss MoA office manages irrigation schemes and has experience in dealing with water provision. In the three other areas, the local MoA offices do not manage water resources for irrigation and consider that groundwater resources are outside their mandate.

Farmers' organisations in the Souss who signed the convention either represent only a minority of large-scale farmers (the case of horticulture exporting associations) or have weak links with grassroots farmers (the case of the Chamber of Agriculture and the federation of water user associations). They do not represent all farmers; not even all farmers who own more than 15 ha. By contrast, a major dairy and citrus cooperative has 14,000 dairy farmer members and has strong links with them, but was not invited to sign the convention. In the three other areas, farmers' organisations are much weaker than in the Souss, and, in practice, have had very limited interactions with the CMAs.

Interviews with farmers revealed a wide range of assessments of the situation of groundwater resources and of possible actions to address their overexploitation. Farmers in the Souss, Saiss and Berrchid regions were generally aware of the links between intensive use of groundwater for irrigation and the drop in the water table (a result also found by Bekkar et al., 2009). By contrast, many farmers in the coastal Chaouia area did not think that groundwater overuse was the main reason for seawater intrusion (Bento et al., 2009). Most farmers considered that the implementation of regulatory tools was above all the responsibility of the State (see also Bekkar et al., 2009). Among the different options they proposed for sustainable groundwater use, only $9 \%$ of Berrchid farmers and no Chaouia farmer mentioned actions to control groundwater use, such as limiting the drilling of boreholes or installing water meters. By contrast, approximately half the farmers in Souss and Saiss mentioned at least one action to control groundwater use. Moreover, half the farmers interviewed in the Souss said that farmers helped the police stop illegal borehole drilling and agreed to the installation of water meters. 
The coalitions considered here are limited to actors who are actively involved in the design and implementation of policies. Indeed, all actors agree about the usefulness of public subsidies to enable a shift to drip irrigation, but in practice only the MoA is involved in the implementation of this policy. The only large coalition is the one that was built during the design of the framework convention in the Souss, but large-scale farmers' involvement in this coalition was fragile, as they were critical of its limited effects in supporting agriculture. Two other more restricted coalitions exist concerning the development of the water resource and the regulation of groundwater use (Table II). In the Souss, large-scale farmers formed an alliance with the MoA to obtain state support for new resources, both for the pipeline bringing water to the El Guerdane sector and for the planned irrigated scheme using desalinized water in the Chtouka region. In the Saiss and Berrchid areas, farmers were much less actively engaged in supporting the mobilisation of new water resources. Coalition building for borehole drilling between the CMA and the Ministry of the Interior appeared to be particularly important for its implementation. Indeed, compared to India (Shah, 2009), the control of borehole drilling (with a focus on the activities of drilling machines rather than on existing wells and boreholes) is not so much an economic issue, but rather of involving the Ministry of the Interior, due to the large presence of agents of this ministry in rural areas. In none of the cases were small-scale farmers part of a coalition.

Table II. Coalitions around policies to deal with groundwater overdraft

\begin{tabular}{lccccc}
\hline Policies & CMA & MoA & $\begin{array}{c}\text { Large- } \\
\text { scale } \\
\text { farmers }\end{array}$ & $\begin{array}{c}\text { Ministry } \\
\text { of the } \\
\text { Interior }\end{array}$ & $\begin{array}{c}\text { Regional } \\
\text { Council }\end{array}$ \\
\hline $\begin{array}{l}\text { Framework convention in the Souss } \\
\text { Mobilisation of new water resources in the }\end{array}$ & $\mathrm{X}$ & $\mathrm{X}$ & $\mathrm{X}$ & $\mathrm{X}$ & $\mathrm{X}$ \\
$\begin{array}{l}\text { Souss } \\
\text { Control of borehole drilling in the Souss, Saiss }\end{array}$ & $\mathrm{X} \quad \mathrm{X}$ (only in & & $\mathrm{X}$ \\
and Berrchid areas & & the Souss) & & \\
\hline
\end{tabular}


Considering each study area individually, there is a large coalition in the Souss, although the involvement of large-scale farmers is precarious. In the Saiss and Berrchid areas, the CMAs are in charge of setting up a large coalition, but are facing difficulties achieving this goal. While in the Souss, public institutions see the framework convention as a common construct, in the Saiss and Berrchid, the aquifer management contract is seen as a tool initiated and owned by the CMAs. In the Coastal Chaouia case, no actor is in charge of building a coalition.

\section{DISCUSSION}

In all the study areas, the CMAs are facing difficulties building coalitions because of the limited number of personnel and their lack of appropriate skills. CMA staff are mainly engineers and technicians trained in water resource sciences but not in agricultural or social sciences. They have limited experience with participatory processes and interactions with farmers. As a result, they find it difficult to coordinate multi-stakeholder processes and to deal with agricultural issues. In the Souss, the framework convention process slowed down when the coordination shifted from the Regional Council - which hired a consultant firm to support the process - to the CMA. Apart from this common constraint, the study areas display a wide range of public policies and supporting coalitions. Four factors explain this diversity.

Depth of the aquifer. The depth of the aquifer influences the speed with which the groundwater economy follows the pattern from growth to maturation and, in case of groundwater overuse, to possible decay (Shah, 2009). Such depth represents the 'buffering capacity' of the aquifer, i.e. the time available for coalitions to be built and policies to be set up. In the Souss, public organisations and farmers have been aware of the groundwater problem for at least 30 years, and groundwater is still mostly available, so the actors have had time to find solutions to deal with the groundwater crisis. By contrast, in the Berrchid and Chaouia areas, which have shallow aquifers, less than 20 years passed between the start of intensive groundwater use and the appearance of an acute groundwater crisis: farmers and local public institutions have had much less time to acknowledge the importance and fragility of the groundwater economy, and to launch discussions over ways to avert the crisis. In that sense, the Chaouia and Berrchid cases are close to the 'exit' category of aquifers coined by Shah (2009), which involves rapid overexploitation of fragile aquifers and farmers hastily moving away from the area. The Souss and Saiss regions, in their current situation, correspond more to the 'collusive opportunism' category defined by Shah (2009), with ever decreasing levels of deep aquifers that may progressively drive smaller-scale farmers away from irrigated farming. Although policies to obtain new water resources and to control groundwater use are 
implemented or planned in these two regions, they have not yet succeeded in halting the drop in the groundwater tables.

Recognition of irrigated farming as the main cause of a groundwater crisis in the local political arena. In the Souss, both farmers and public institutions have long understood the impacts of irrigation on the aquifer. As mentioned above, farmers in the coastal Chaouia area acknowledge only a limited link between groundwater overuse and seawater intrusion. Moreover, in this region many farmers and some staff of the local MoA offices think that one major cause of the groundwater crisis is the building of a dam on the Oum Er-Rbia River in the 1990s, although this river in fact drains water from the aquifer.

The importance of the groundwater economy in the regional and national economy. The attention actors pay to the problem of groundwater overuse is influenced by its relative importance compared to non-agricultural activities or to rainfed agriculture. The Souss is a much drier area than the Saiss, where many crops can be rainfed. In addition, in the Souss, citrus and vegetables for export, which rank first in Morocco, have required major investments, and are grown on large-scale farms with strong lobbying capacities vis-à-vis the public administration. In comparison, the economic activities generated by the use of the Chaouia and Berrchid aquifers are only small components of the economy of the Doukkala Abda and Chaouia Ouaragha regions.

The motivation and capacities of actors to engage in policies for the sustainable use of groundwater. The motivation of public organisations to take an active stance in policies dealing with groundwater overdraft depends on the importance of the aquifer in the area they manage. Addressing the groundwater crisis was at the top of the agenda of both the Souss-Massa Regional Council and the CMA. By contrast, the Saiss aquifer is shared between two regions, and neither of the Regional Councils took an active stance towards groundwater management. Souss farmers are mostly land owners and are strongly integrated in local communities (Faysse et al., 2010). By comparison, in the Berrchid region, many farmers rent land, and villages are scarce, hence the farmers are much less attached to either the land or the community. In the Souss, some farmers' organisations were sufficiently organised to play an active role in negotiations with public organisations. In the Chaouia and Berrchid there are far fewer farmers' organisations and those that exist are much weaker.

The three last factors are close to those identified by Ostrom (2000) concerning the characteristics of appropriators enabling self-management of common-pool natural resources. Indeed, among the factors that Ostrom identified: i) the common understanding of the resource relates to the second of the four above-mentioned factors; ii) the dependence of appropriators on the resource system for a major portion of their livelihood relates to the third one; and iii) the 
low discount rate for the future and prior organisational experience relate to the fourth.

However, assessing these factors should not lead to underrating the importance of the negotiation processes, with their due share of contingencies and path dependencies. In addition, these factors may change over time. Thus, these factors should not be considered as elements that could be used to separate situations in which large coalitions may reach sustainable groundwater use and others which are doomed to a tragedy of the commons. Rather, they should be considered as a guide to identifying which coalitions should be supported, which stumbling blocks need to be removed to reach relevant coalitions, and to identify the most appropriate policies that these coalitions may be able to design and implement. In the Souss and Saiss regions, collaboration with farmers' organisations could be reinforced, so as to tap the farmers' predisposition for the establishment of regulatory instruments, provided the latter are implemented in an equitable way. In the Chaouia and Berrchid regions, CMA staff could be specifically mandated to catalyze coalitions and to create a local dynamics to address the groundwater crisis.

\section{CONCLUSION}

In the recent past, several policies have been implemented to deal with the increasing groundwater crisis in Morocco, both in terms of demand and supply management. Many of these policies did not remain 'on paper', and, in particular, the activities of the water police have already had considerable impacts on the ground. The types of policies implemented differed widely between the study areas, mostly because of different supporting coalitions of actors.

However, despite the administration's stated objective of building large coalitions, existing coalitions are limited both in their number of members and in their objectives. Smallscale farmers are not included in the already strong coalition between Souss large-scale farmers and the MoA for developing new water resources, nor are they part of the increasingly influential coalitions involving the CMAs and the Ministry of the Interior for implementing the water police. Moreover, groundwater governance has only made limited appearances in local public arenas. Aquifers have thus turned into a 'space of dependence' but have not yet become a 'space of engagement' (Venot et al., 2011).

In the future, the CMAs will remain key actors in building large coalitions. However, they need to move from a posture of law enforcement, from which they derive their power and legitimacy, to one that places much more emphasis on coalition building, and this requires new skills. Moreover, as the water police become more present on the ground, the even-handedness 
with which this police force controls farmers will evolve into an increasingly contested issue. Transparent monitoring of its functioning will be increasingly necessary. Finally, innovative ways to include small-scale farmers in coalitions should be supported, particularly by engaging with the many active farmers' organisations at local level (Faysse et al., 2010), even though these organisations may not be formally involved in water resource management.

\section{REFERENCES}

Bekkar Y, Kuper M, Errahj M, Faysse N, Gafsi M. 2009. On the difficulty of managing an invisible resource: the use of groundwater for irrigation. Irrigation and Drainage 58: $252-263$.

Bento S, Driouech F, Errahj M, Faysse N, Garin P, Richard Ferroudji A, Rinaudo JD, Rollin D, Schmidt L, Varanda M. 2009. Farmers' relations to climate variability and changes: the case of groundwater users of coastal aquifers in France, Portugal and Morocco. Ninth conference of the European Sociological Association, Lisbon, Sept, $3^{\text {rd }}$.

Berrahmani A, Faysse N, Errahj M, Gafsi M. submitted. Chasing water: Diverging farmers' strategies to face the groundwater crisis in the coastal Chaouia region in Morocco. Submitted to Irrigation and Drainage.

Birkenholtz T. 2009. Groundwater governmentality: hegemony and technologies of resistance in Rajasthan's (India) groundwater governance. The Geographical Journal 175(3): 208220.

Errahj M, Faysse N, Mounir A, Labbaci T, Flissi M, Layadi A. 2009. Diagnostic des pratiques d'exploitation des eaux de la nappe de Berrchid. Enquête exploitation agricole. Ecole Nationale d'Agriculture de Meknès, unpublished document.

Faysse N, Errahj M, Kuper M, Mahdi M. 2010. Learning to Voice? The evolving roles of family farmers in the coordination of large-scale irrigation schemes in Morocco. Water Alternatives 3(1): 48-67.

Faysse N, Petit O. 2012. Convergent readings of groundwater governance? Engaging exchanges between different research perspectives. Irrigation and Drainage, this volume.

Gramsci A. 1971. Selections from the Prison Notebooks. International Publishers, New York.

Houdret A. 2008. The privatisation of irrigation water services: New partnerships and water conflicts in the El Guerdane project, Morocco. Thirteenth World Water Congress, International Water Resources Association, Montpellier, France, 1-4 September 2008.

Lopez-Gunn E, Martinez-Cortina L. 2006. Is self-regulation a myth? Case study on Spanish 
groundwater user associations and the role of higher-level authorities. Hydrogeology Journal 14: 361-379.

Mollinga PP, Meinzen-Dick RS, Merrey DJ. 2007. Politics, plurality and problemsheds: A strategic approach for reform of agricultural water resources management. Development Policy Review 25(6): 699-719.

Moroccan Secretariat in Charge of Water and Environment. 2007. Débat National sur l'Eau. Unpublished document downloaded on Nov, $1^{\text {st }}, 2011$ from gc21.inwent.org/.../iii\%20Debat\%20sur\%201'Eau.pdf.

Mukherji A. 2006. Political ecology of groundwater: the contrasting case of water-abundant West Bengal and water-scarce Gujarat, India. Hydrogeology Journal 14: 392-406.

Mukherji A, Shah T. 2005. Groundwater socio-ecology and governance: a review of institutions and policies in selected countries. Hydrogeology Journal 13:328-345.

Ostrom E. 2000. Reformulating the commons. Swiss Political Science Review 6(1): 29-52.

Petit O. 2009. La politique de gestion des eaux souterraines en France. Une analyse en termes de gestion intégrée. Economie Rurale 309: 50-64.

Pfeiffer L, Lin CY. 2010. The effect of irrigation technology on groundwater use. Choice, 25(3).

Popp H. 1983. Un 'man-made hazard': le surpompage de la vallée du Souss. Revue de Géographie Marocaine 6: 35-51.

Schlager E. 1995. Policy making and collective action: Defining coalitions within the advocacy coalition framework. Policy Sciences 28: 243-270.

Shah T, Burke J, Villholth K. 2007. Groundwater: a global assessment of scale and significance. In Water for Food, Water for Life: A comprehensive assessment, Molden D (ed.). IWMI/Earthscan: London.

Shah T. 2009. Taming the anarchy. Resource for the Future Press.

Shah T. 2012. Community Response to Aquifer Development: Distinct Patterns in India's Alluvial and Hard rock Aquifer Areas. Irrigation and Drainage, this volume.

Ward FA, Pulido-Velazquez M. 2008. Water conservation in irrigation can increase water use. PNAS 105: 18215-18220.

Wester P, Sandoval Minero R, Hoogesteger J. 2011. Assessment of the development of aquifer management councils (COTAS) for sustainable groundwater management in Guanajuato, Mexico. Hydrogeology Journal 19: 889-899. 